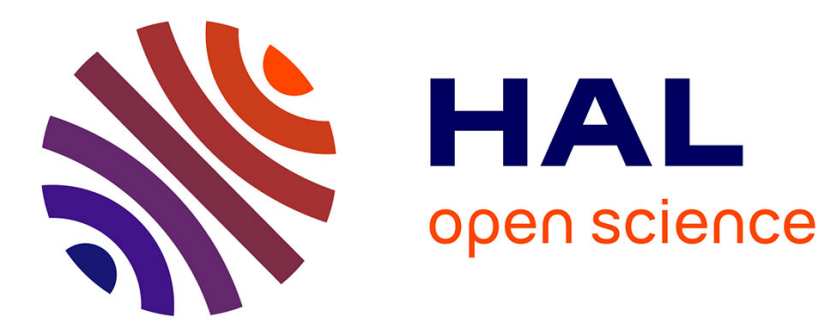

\title{
Ethynylglycine synthon, a useful precursor for the synthesis of biologically active compounds: an update
}

Zohra Benfodda, David Bénimélis, Gianna Reginato, Patrick Meffre

\section{To cite this version:}

Zohra Benfodda, David Bénimélis, Gianna Reginato, Patrick Meffre. Ethynylglycine synthon, a useful precursor for the synthesis of biologically active compounds: an update: Part I: preparations of ethynylglycine synthon. Amino Acids, 2015, 47 (2), pp.271-279. 10.1007/s00726-014-1902-0 . hal01676812

\section{HAL Id: hal-01676812 \\ https://hal.science/hal-01676812}

Submitted on 11 Jan 2018

HAL is a multi-disciplinary open access archive for the deposit and dissemination of scientific research documents, whether they are published or not. The documents may come from teaching and research institutions in France or abroad, or from public or private research centers.
L'archive ouverte pluridisciplinaire HAL, est destinée au dépôt et à la diffusion de documents scientifiques de niveau recherche, publiés ou non, émanant des établissements d'enseignement et de recherche français ou étrangers, des laboratoires publics ou privés.

\section{(ㅇ)(1) $\$$}

Distributed under a Creative Commons Attribution - NonCommercial - NoDerivatives 44.0 


\title{
Ethynylglycine synthon, a useful precursor for the synthesis of biologically active compounds: an update
}

\author{
Part I: preparations of ethynylglycine synthon
}

\author{
Zohra Benfodda - David Bénimélis · Gianna Reginato · \\ Patrick Meffre
}

\begin{abstract}
The ethynylglycine synthon $\{(R)$-2,2-dimethyl3-(tert-butoxycarbonyl)-4-ethynyloxazolidine $\}$ is a chiral compound with valuable synthetic interest. An update on the different routes for its synthesis is reviewed and discussed.
\end{abstract}

Keywords Synthesis - Ethynylglycine synthon . Bestmann-Ohira $\cdot$ Corey-Fuchs

\begin{tabular}{ll}
\multicolumn{2}{l}{ Abbreviations } \\
Boc & Tert-butoxycarbonyl \\
Cbz & Benzyloxycarbonyl \\
DIBAL-H & Diisobutylaluminum hydride \\
TEMPO & 2,2,6,6-Tetramethylpiperidine 1-oxyl \\
Ts & 4-toluenesulfonyl \\
ent-x & Enantiomer of compound $\mathbf{x}$
\end{tabular}

\section{Introduction and goals}

Ethynylglycine synthon 1a (Fig. 1) was reported for the first time, but independently, by us (Reginato et al. 1995; Meffre et al. 1995).

Z. Benfodda · D. Bénimélis · P. Meffre $(\varangle)$ IBMM-UMR 5247-CNRS-Universités Montpellier 1 et 2, Place E Bataillon, 34095 Montpellier Cedex 5, France e-mail: patrick.meffre@unimes.fr

Z. Benfodda · D. Bénimélis · P. Meffre UNIV. NIMES, EA7352 CHROME, Rue du Dr G. Salan, 30021 Nîmes Cedex 1, France

G. Reginato

ICCOM-CNR, Via Madonna del Piano 1, 50019 Sesto Fiorentino, Italy
In 2005, we published a mini-review in this journal about the use of ethynylglycine synthon 1a in the synthesis of non-natural amino acids (Reginato et al. 2005).

Nearly 10 years later, it is time to update the knowledge on the synthesis and use of 4-ethynyloxazolidine, showing the broad range of synthetic applications of this compound. Although some commercial sources are available, ethynylglycine synthon 1a has usually to be prepared. Therefore, we will focus in the present review (part I) on the preparations of this compound (and its derivatives) described in the literature so far. The synthetic strategy adopted and the preferred protection for the amino protecting group will be discussed. Part II of this review will be devoted to the uses of ethynylglycine synthon in synthesis and will be published later.

Oxazolidine 1a is prepared from Garner's aldehyde 2a (Garner 1984; Garner and Park 1987; Meffre et al. 1994). For recent reviews on serinal derivatives of type 2, see Passiniemi and Koskinen (2013) and Bera et al. (2013).

Two strategies have been used. In the first one, oxazolidine 1a is prepared from $\mathbf{2 a}$ via direct aldehydeto-alkyne one carbon homologation using dimethyl 1-diazo-2-oxopropylphosphonate $\mathbf{3}$ (Bestmann-Ohira reagent, diazo strategy, method A) (Fig. 2; Ohira 1989). This method is also reported as Seyferth-Gilbert strategy.

The second strategy is a two steps sequence via dibromovinyl intermediate (Corey-Fuchs strategy, method B) (Fig. 2; Corey and Fuchs 1972). Table 1 gives an overview of all the methods used in the literature to prepare ethynylglycine synthon 1a. Whenever possible, yield, scale, information on synthetic protocols detailed in the paper as well as the specific rotation of $1 \mathrm{a}$ are reported in Table 1. 


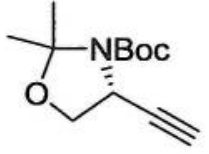

$1 \mathrm{a}$

Fig. 1 (R)-2,2-dimethyl-3-(tertbutoxycarbonyl)-4-ethynyloxazolidine \{ethynylglycine synthon\}

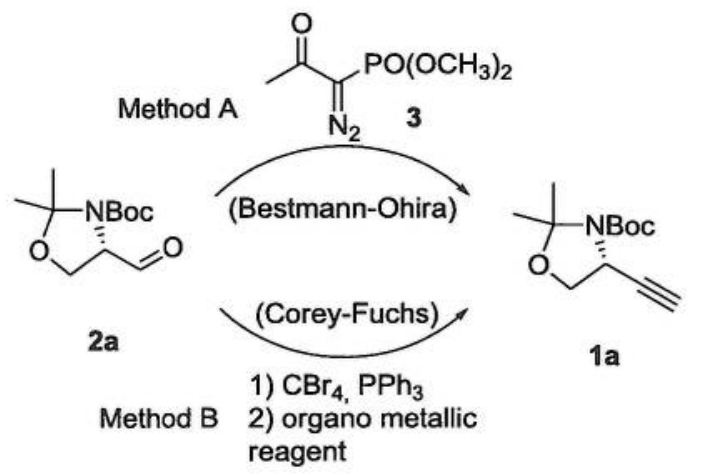

Fig. 2 The two strategies to synthesize ethynylglycine synthon 1a<smiles>CO[Po](C)C</smiles>

4

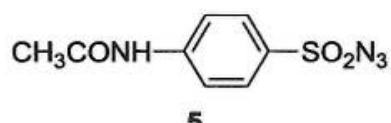

5
Fig. 3 The starting materials for in situ synthesis of 1a from 2a (Meffre et al. 2002)<smiles>COC(=O)[C@@H]1COC(C)(C)N1C(=O)OCc1ccccc1</smiles><smiles></smiles>

Fig. 4 Precursors for aldehyde 2a

\section{Ethynylglycine synthon synthesis using Bestmann-} Ohira strategy $(\operatorname{method} A)$

Because the conditions required to prepare BestmannOhira reagent $\mathbf{3}$ are compatible with the aldehyde-toalkyne transformation procedure, we have improved the reported synthetic methods, describing a simple one-pot multicomponent process (Meffre et al. 2002) for the preparation of $1 \mathbf{a}$ from aldehyde $\mathbf{2 a}$. This involves the in situ formation of dimethyl 1-diazo-2-oxopropylphosphonate 3 from commercially available phosphonate $\mathbf{4}$ and diazo transfer reagent 5 (Fig. 3). Although the reaction seems to be slower with 4-acetamidobenzenesulfonyl azide $\mathbf{5}$ compared to the usually reported tosyl azide (TsN3), the former was preferred as diazo transfer reagent. Being a crystalline solid, it is easier to manipulate and to prepare in a pure form, and is known not to exhibit impact properties.

Garner aldehyde 2a can be obtained either by ester reduction or alcohol oxidation, and should be possibly used without purification to avoid a possible racemization. This was shown by Pietruszka et al. (2003) which used crude aldehyde $2 \mathrm{a}$ obtained either by reduction of ester $\mathbf{6}$ using DIBAL-H, or by oxidation of alcohol 7 using Dess-Martin periodinane (Fig. 4) together with Bestmann-Ohira reagent 3.

The aldehyde-to-alkyne homologation can be performed directly starting from aldehyde precursors too: ester 6 (Branquet et al. 1993) and alcohol 7 (Meffre et al. 1994) (Fig. 4). Taking advantage of the mild nature of BestmannOhira reaction, Dickson et al. (2004) reported a two step one-pot synthesis of ent-1a using strategy A with methyl ester ent-6 as starting material, non-isolated intermediate aldehyde ent-2a being obtained by DIBAL-H reduction.

Belanger et al. (2009) used alcohol 7 as starting material which was oxidized into aldehyde $2 \mathrm{a}$ using TEMPO (no specific rotation is given for intermediate $\mathbf{2 a}$ ). The aldehyde was directly engaged in the aldehyde-to-alkyne homologation. However, the specific rotation of alkyne 1a obtained in this way is reported to be much lower compared to other procedures which could be interpreted as a loss in enantiomeric purity during TEMPO oxidation.

\section{Ethynylglycine synthon synthesis using Corey-Fuchs strategy (method B)}

When the Corey-Fuchs strategy (Method B) is used, a dibromovinyl intermediate $\mathbf{8}$ is generated in the first step of the reaction which is reacted with BuLi to give the corresponding alkyne (Fig. 5). Variable amounts of enamine $9 \mathbf{a}$ are always formed in this transformation. This byproduct is generally present in very small amounts (lower than

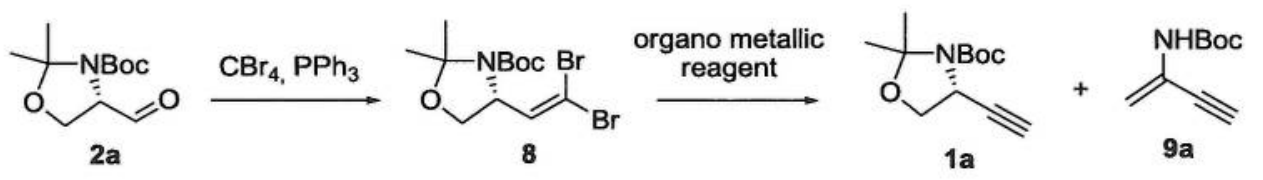

Fig. 5 The Corey-Fuchs strategy (method B). Degradation product 9a observed in the preparation of 1a (variable amounts) 
$10 \%)$ and became predominant only when a large excess of base was used for prolonged reaction times (Reginato et al. 1995, 1997; Meffre et al. 1995, 1996; Branquet et al. 1998).

The use of a Grignard reagent as base in the second step proved to be better than $\mathrm{BuLi}$, minimizing ring degradation and formation of enyne 9a. Erdsack and Krause (2007) showed that use of propylmagnesium chloride gave excellent
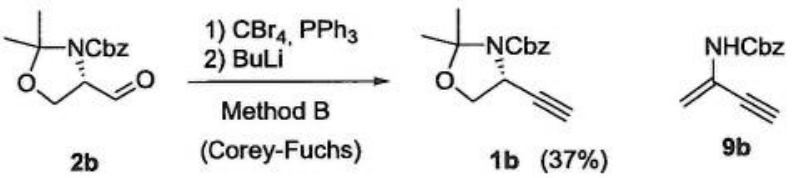

Fig. 6 Preparation of Cbz-protected ethynylglycine synthon 1b (Reginato et al. 1998)

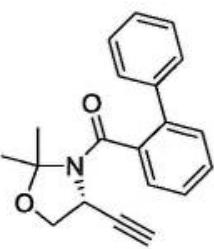

$1 c$

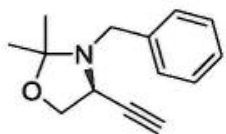

1d
Fig. 7 Ethynylglycine synthons with $o$-phenylbenzoyl (1c) or benzyl (1d) as a $N$-protecting group (Ayed et al. 2010a, b) yields, proving to be even more convenient than the Bestmann-Ohira reagent (method A). Analogously, Yamakawa et al. $(2010,2011)$ used ethylmagnesium bromide.

This strategy has also been used in the synthesis of both enantiomers of $\alpha$-ethynylalanine (Avenoza et al. 1999).

\section{The amino protecting group issue}

Reginato et al. (1998) enlighted the role of the amino protecting group in the Corey-Fuchs strategy (method B) using $\mathrm{BuLi}$ as base. While enyne $9 \mathrm{a}$ can be formed in variable amounts with Boc protected oxazolidine 2a (Garner's aldehyde), formation of enyne $9 \mathbf{b}$ was never observed in the reaction mixture when $\mathrm{Cbz}$ protecting group was used. Thus, $\mathbf{1 b}$ was obtained from $\mathbf{2 b}$ using method B, however, the transformation proved to be less efficient (Fig. 6).

Ayed et al. (2010a) described the synthesis of 1c using $o$-phenylbenzoyl group as a $\mathrm{N}$-protecting group (Fig. 7). This was necessary as the Boc group was not compatible with indium(0)-mediated coupling reaction of alkynyl iodide 10 which gave cyclic compound 11 because of Boc participation, instead of the $C$-glycosylated derivative 12. In this case, the authors proposed a reduction with indium $(0)$ of the carbamate moiety in $\mathbf{1 0}$ followed by a cyclization on the triple bond activated by indium(I) to give 11 (Fig. 8).
Fig. 8 Indium mediated reduction of carbamate and cyclization (Ayed et al. 2010a)<smiles>[R6]N1[C@@H](C#C)COC1(C)C</smiles>

$1 \mathrm{a}$

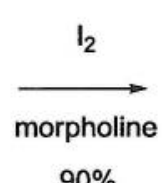

$90 \%$<smiles>CC1(C)OC[C@@H](C#CI)[N+]1(C)O</smiles>

10

In $91 \%$<smiles>CC1(C)OC[C@H]2/C(=C/I)OC(=O)N21</smiles>

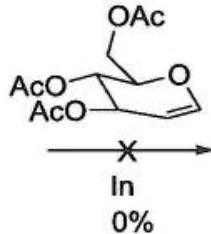

$0 \%$<smiles>CC(=O)OC1C=CC(OC(C)=O)C(C#C[C@@H]2COC(C)(C)N2C(C)(C)C)O1</smiles>

Fig. 9 Introduction of $o$-phenylbenzoyl and benzyl $\mathrm{N}$-protecting groups for the syntheses of $1 \mathrm{c}$ and $1 \mathrm{~d}$ (Ayed et al. 2010a, b; Barco et al. 1992)

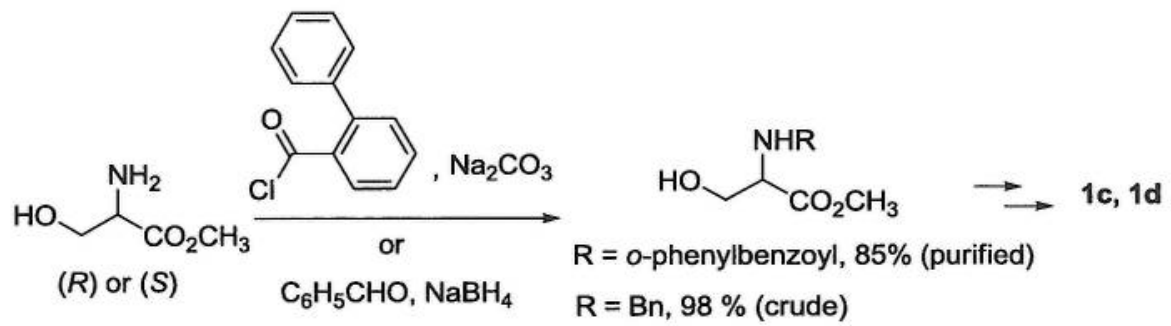


Fig. 10 Nucleophilic attack of Boc group under Larock's iodocyclization condition

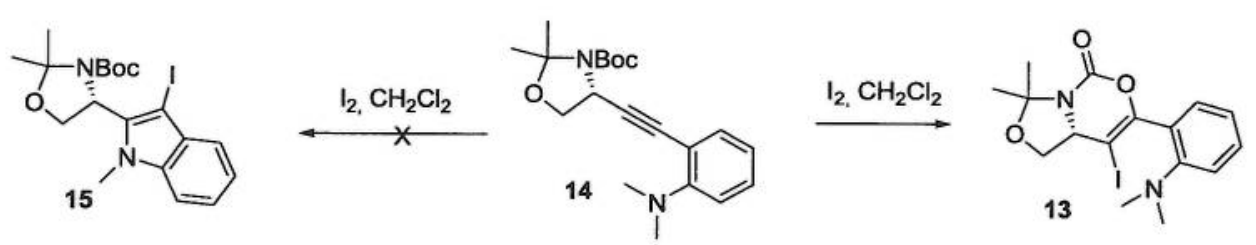<smiles>C#CC1COC(C)(C)N1C(=O)O</smiles>

1a

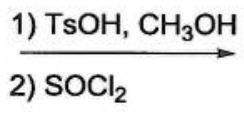

2) $\mathrm{SOCl}_{2}$

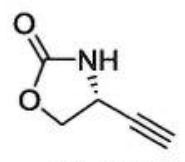

$16(49 \%)$
Fig. 11 Synthesis of ethynyloxazolidinone 16 from ethynylglycine synthon 1a<smiles>C#C[C@@H]1COC(=O)N1</smiles>

16<smiles>C#C[C@H]1COC(=O)N1CC=C=C</smiles>

17
Fig. 12 4-Ethynyloxazolidin-2-one derivatives 16 and 17 as ethynylglycine synthons

The same group described also ethynyloxazolidine 1d with a benzyl amino protecting group (Ayed et al. 2010b; Fig. 7). The synthesis of $\mathbf{1 c}$ and $\mathbf{1 d}$ are described from L- or D-serine methyl ester hydrochloride in good overall yield and full analyses are given (Ayed et al. 2010a, b; Barco et al. 1992; Fig. 9).
Again, the participation of Boc protecting group (nucleophilic attack) under Larock's iodocyclization conditions $\left(\mathrm{I}_{2}, \mathrm{CH}_{2} \mathrm{Cl}_{2}\right)$ was reported by Goswami et al. (2012b). In this case compound $\mathbf{1 3}$ was formed from 14 instead of expected indole derivative 15 (Fig. 10).

To solve this problem, ethynylglycine synthon 1a was transformed into ethynyloxazolidinone 16, through the removal of acetonide protection and reaction of the resulting amino alcohol with thionyl chloride (experimental details and analyses are given for this compound) (Fig. 11).

Synthesis of 2-indolylglycine derivatives using Sonogashira coupling followed by cyclization was then possible using ethynyloxazolidinone $\mathbf{1 6}$ as starting material.

In the oxazolidinones family, allenyne $\mathbf{1 7}$ was also obtained from the corresponding aldehyde using Bestmann-Ohira reagent (method A) (Kumareswaran et al. 2004; Fig. 12). This compound represents an advanced intermediate for the synthesis of highly functionalized pyrrolidines such as kainic acids or its congeners.

It is worth to highlight, however, that alkynes 1a-d, 16 and 17 seem to be the only optically active cyclic ethynylglycine synthon derivatives described in the literature so far.

It should be also remarked that nucleophilic substitution at alkoxide of amino alcohol derived from oxazolidine ring opening is strongly dependent on the amino protective<smiles>C#CC(COc1nncc([Al])n1)NC(C#C)COc1nncc([Al]CC(C#C)NC(C#C)C(=O)OCc2ccccc2)n1</smiles>

Fig. 13 Different behavior of ethynylglycine synthon derivatives protected with Boc or Cbz groups towards nucleophilic substitution (Ar is an aromatic substituent)

Fig. 14 Synthesis of alkynes 22 and 23<smiles>CC(=O)OC1OC(C)(C)[NH+]([18O])C1C=O</smiles>

24<smiles>COPC(=NC(C)=O)[Po](=O)OC</smiles>

(method A)<smiles>C#CC1C(C(=O)OC)OC(C)(C)C1(C)C</smiles>

22 (96\%)

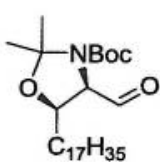

25

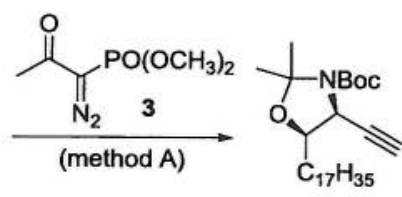

$23(87 \%)$ 


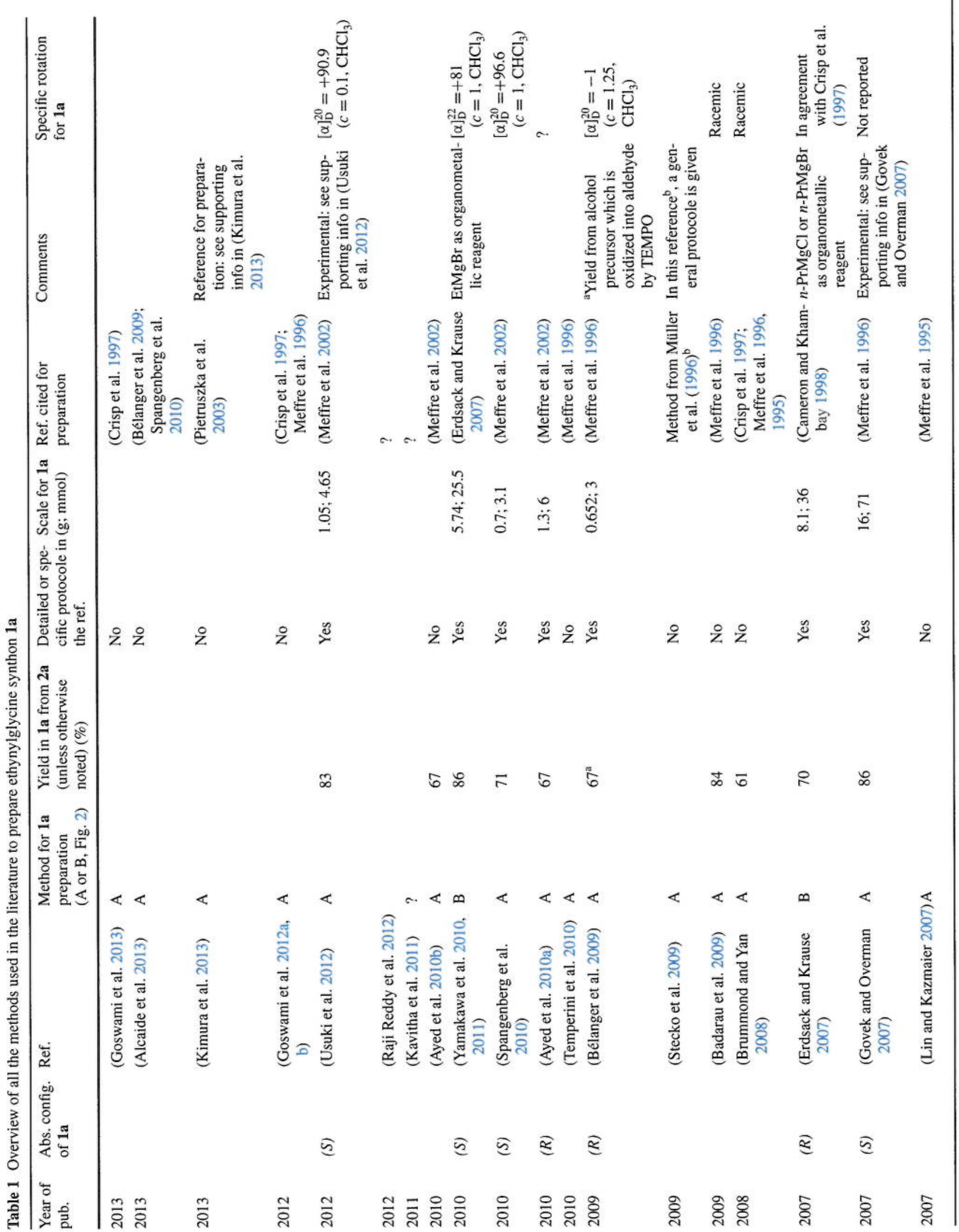




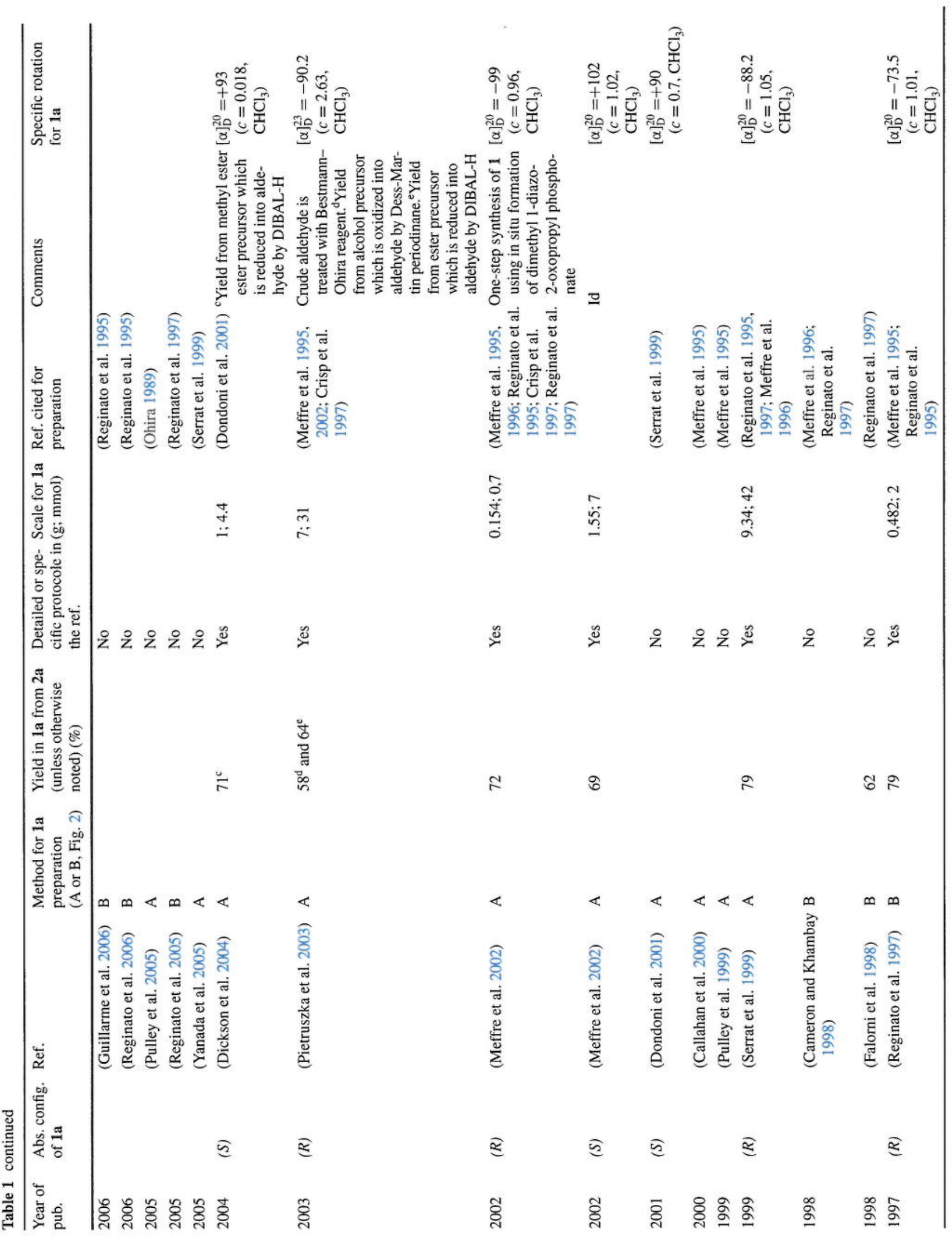




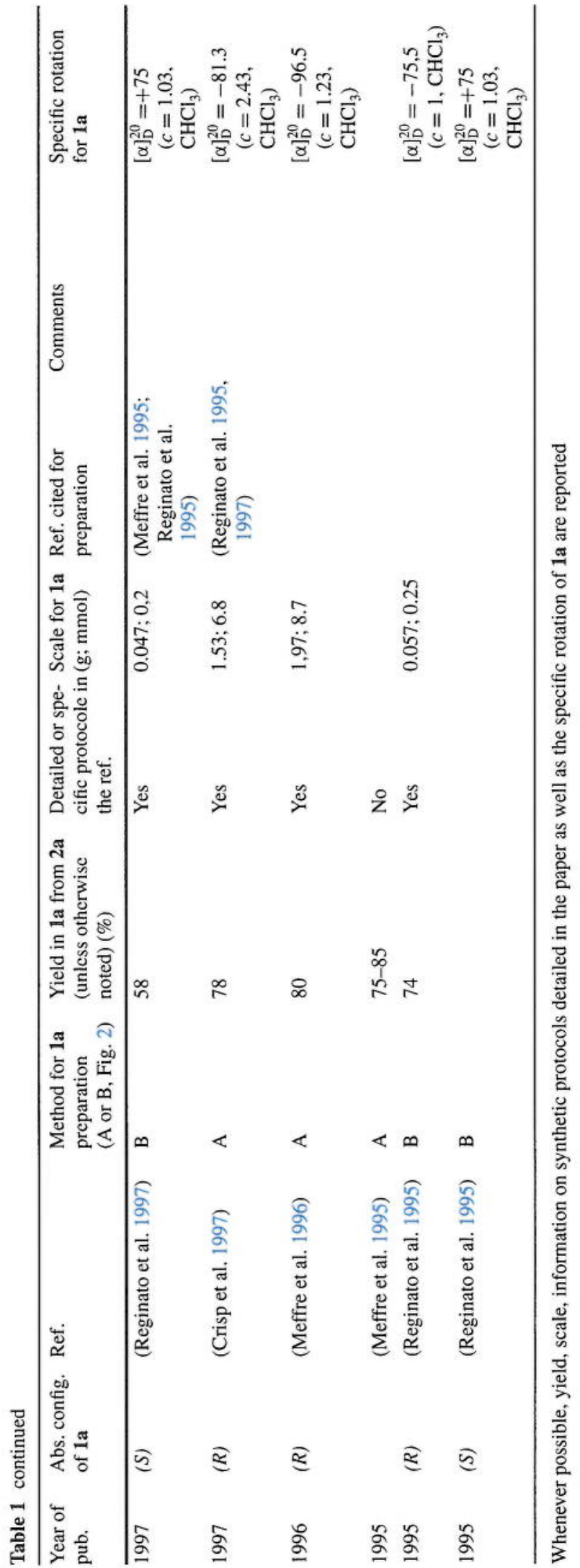

group, especially if potential leaving groups are present. This is illustrated in Fig. 13, where methylsulfonyl group substitution gave the formation of an oxazolidinone rac-16 as a side product when carried out on Boc derivative $\mathbf{1 8}$ instead of Boc derivative 19. This is due to cyclization of the alkoxide derived from 18. However, it proved to be possible to perform the reaction using $\mathrm{Cbz}$ protected amino alcohol 20 yielding to $\mathrm{Cbz}$ derivative 21 (Badarau et al. 2009). The authors highlighted the importance "to try different protecting groups of the amine moiety that did not incorporate potential leaving group in their structures" (Badarau et al. 2009). This can be explained by a difference in leaving group ability of tertbutoxide group compared to benzyloxide group which favour an internal nucleophilic attack in the case of Boc group leading to rac-16. Both compounds $\mathbf{1 8}$ and $\mathbf{2 0}$ are derived from racemic ethynylglydine synthon $r a c-1 a$.

\section{Note in addition}

Alkynes 22 and $\mathbf{2 3}$, closely related to ethynylglycine synthon 1a were synthesized from their aldehyde precursors 24 and 25 , respectively, using method A in very good yields (Fig. 14; Debnar et al. 2013; McDonagh and Murphy 2014, respectively).

\section{Conclusion}

Six optically active cyclic ethynylglycine synthons $1 \mathrm{1a}-\mathbf{d}, \mathbf{1 6}$ and 17 have been described in the literature. The most popular is the ethynyloxazolidine 1a with Boc as amino protecting group. It has been prepared from serine via Garner aldehyde $2 \mathbf{a}$ as key intermediate, the alkyne being obtained from the aldehyde either directly using Bestmann-Ohira reagent or the two steps Corey-Fuchs transformation. Several protocols have been described in the literature for both methods and have been collected in Table 1. The best should be probably selected depending on the synthetic application desired. Protection of the amino group might be a crucial issue as shown in many cases. Particularly, the Boc group might have an influence (participation) in the synthesis of 1a but also can play an important role when this chiral synthon is used in multistep synthesis (see part II).

Conflict of interest The authors declare that they have no conflict of interest.

\section{References}

Alcaide B, Almendros P, Quirós MT, Fernández I (2013) Gold-catalyzed oxycyclization of allenic carbamates: expeditious synthesis of 1, 3-oxazin-2-ones. Beilstein J Org Chem 9(1):818-826 
Avenoza A, Peregrina JM, Sucunza D, Zurbatio MM (1999) A

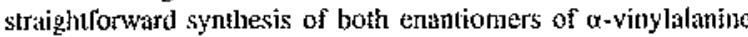
ardl a-ethylylatanine. Telraluedron Asymmelry 10(23);4653-4661

Ayed C, Palmier S, Lubin-Germatin N. U7iel J, Auge J (2010a) Indium-nuediated alkynylation of sugars: syuthesis of C-glycosyl componnds bearing a profected anino alcohol troiety. Carbohyd $\operatorname{Res} 345(17)+2566-2570$

Ayed C. Pieard J, Lubif-Germain N, Uziel J, Auge J (20100) 5ynthesis of akynos and atkynyl todides beatring a protected antioo alcohol noicty as functionalized amino acids preculsors. Science China Clumisty $53(9): 1921-1926$

Badaral E. Surenet F, Finan AL. Guillaufuet G (2009) Synthesis of 3-Amino-8-azactiromans and 3-Amino-7-azahenzofurans via Inverge Electron Dentand Diels-A dder Reaction. Eur J Org Chen $21: 3619-3627$

Barco A. Bencli S. Spalluto G, Casolari A, Pollini GP, Zanirato $V$ (1992) A new approech to kainoids throngh tandem Michacl rekction methodology: application to the entatioselective synthesis of $(+)$-and $(-)-\alpha$-allokinicic acid and to the formal synthesis of (-)-c(kainic acid. J Org Chen 57(23):6279-6286

Belanger D, Tong $X$, Soumar S. Dory YL, Zhao $Y$ (2009) Cyclic peptide-polymer complexcs and their sel I-assembly. Chem Eur J $15(17): 4428-4436$

Bera $S$, Mondal D, Singh M, Kale RK (20I3) Adwanees in serinals for asymmetric synthesis. Tetrabedron 69(3):969-1011

Branquet E, Durafl P, Vo-Quang L, Le Goffic F (1993) A siraighttorward synthesis of N-lert-butoxycarbony! serinate acetonide metlyl ester. Synth Comnun 23(2); $153-156$

Branquet E, Meffre P, Durand P, Le Gorfic F (1998) Synthesis of Now Chiral Vinyl Halides from L-Serinal. Synt Commun 28(4):613-622

Brymmond KM, Yan B (2008) Rlodium (i)-catalyzed cyeloisomerization reaclion of yntallenantides; an approach to cyclic enanides. Syntel 15:2303-2308

Callahtn JP., Khatana SS, Bhatnagar PK (2000) Stertoselective syr thesis of diaminosuberic acid via a chiral alkynyl oxazolidine. Synul Commun 30(7): 1213-1219

Caneror. S, Khambay BP (1998) Stereospecific synthesis of the thino acid, $(S)-2$-annino-(Z)-3, 5-lucxátienoic acid. Tetrahedron Le1t 39(14): 1987-1990

Corey EJ, Fuchs PL (1972) A synthelic nelhod for Jorny] $\rightarrow$ ellyy nyl conversion (RCILO $\rightarrow$ RCCH or RCCR ${ }^{f}$ ). Tellahedron Lett I3(36):3769-.3772

Crisp Gr, Jinng YL, Puftman Pl, De Savi C (1997) Elaboration of the side-chain of amizo aeid derivatives by palladium catatysed conplings. Tetrahedron $53(51)+17489-17500$

Dehnar 'f, Wang T. Menclie D (2013) Stcreosclective synthesis of the butyrolactone and the oxazoline/turas fraisnent of Jeupyrin A1. Org Eett $15(1 \mathrm{t}): 2774-2777$

Dickson HD. Smitl SC, Hinkle KW (2004) A conyenient sctable one-pot conversion of esters and Weingeb amides to terrainal atkynes. Tetrilnedron Lett 45(29):5597-5599

Dondoni A. Mariotli G. Marra A, Massi A (2001) Expeditious synthesis of B-linked glycosyl scrine methylene isoseres ( $\beta$-c-gly ser) via ethynylation of sugar lactones. Synthesis 14:2125-2:37

Erdsack J, Krase N (2007) Synthesis of furanomycin derivatives by gold-catalyzed cycloisomerization of $\alpha$-hydroxyallenes. Synthesis $23: 3741-3750$

Fulomi $M$, Giacomelli G, Spanu E (1998) Syathesis of new a-aminoucids contaning the isoxazole moiety. Tetrahedron Let $39(50) \div 9241-9244$

Gather P (1984) Stercocontrolled addition to a penaldic acid equiva-

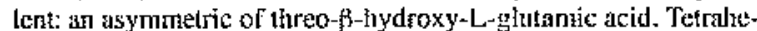
dron Letl 25(51) $\$ 5855-5858$

Garner 1, Park JM (1987) The syntluesis and confogurglionat stability of differentially protected beta -hydroxy-atphti-amino aldelydes. J Org Chen $52(12) \div 2361-2364$
Goswanj K, Chakraborty $A$, Sinha $S$ (2013) Synthesis of optically aclive selenium-containing tsotryptoplian, homotsoltyptophat, and honotryptophan. Eur J Org Chem 18:3645-3647

Goswami K. Dutagopta E. Sirha S (2012a) Synthesis of optically aclive 2-and 3-indolylglycine cerivatives and their oxygen analoyues. J Org Chem 77(16):708 1-7085

Goswami K, Paut S, Bugde ST, Sinha S (2012h) Synthesis of opticalty active homotryptophan and its oxygen and sulfur antogics. Telrabeciron $68(1): 280-286$

Govek SP, Overman LE (2007) Total synthesis of (+)-asperazine. Telratiedron $63(35): 8499-8513$

Guilanne S, Ple K, Haudredyy A (2006) Selective synthesis of $\alpha-C$ (alkyny)-galaclosides by an efficient tanderm reaclion. J Org Chem 71(3): 1015-1017

Kavitha M, Mahipal B, Mainkar PS, Clandrasekhar S (20f I) Click reaction on in situ gencrated p-izidostyrenes from cinnanic acid

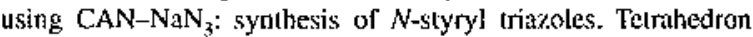
Lett $52(14) \div 1658-1662$

Kimura $Y$, Ito S, Shimizu Y, Kanai M (2013) Calatytic anomoric aminoalkynylation of unptolected aldoses. Org Lel? $15(16): 41304133$

Kumereswuran R, Shin S, Gallou [, RajanBabu TV (2004) Silylstannylation of alleres and silylstamylation-cyctization of allenyes. Synthesis of highly funclionatized allylstannanes and carbocyclic and heturocyclic compounds. I Org Chem $69(21): 7157-7170$

Lin H, Kazmuter L (2007) Resioselective mo-catalyzed hydrostannations as key steps in the syrthesis of functionalized andino alcohols and lyeterocycles. Eur ] Org Chem i 7:2839-2843

McDonath AW, Muthy PV (2014) Sytthesis of a-galnctosyl ceranide antogues with an $\alpha$-triazole at the anoneric carbon. Tetrahedron 70(19):3191-3196

Meffe P. Durand P. Bratuquel E, Le Goftic F (1994) A straightforward synthesis of N-Boc-t,-serinal and N-Boc-L-threoninal acelonides. Synth Comm 24(15):2147-2152

Meffe P, Gauzy E. Perdigues C. Desanges-Levecque F, Branguet E, Durand P, Le Goffic F (1995) En route to optically actire chynylglycine derivatives. Tetrahedron Lett $36(6): 877-880$

Melfie P. Gauzy L, Branquet E, Durand P. Le Goffic F (1996) Synthesis of optically active $P, \gamma$-alkynyiglycine derwatives. Tetrahedron 52(34): ] 1215-] 1238

Melle P, Hermann S, Durand P, Reginato G, Riu A (2002) Practical one-slep synthexis of ethynylglycite syothon from Gatuce's aldeiyde. Tetralyedron $58(25) \div 5159-5162$

Mtiller S, Liepotd B, Rolh GJ, Besimam H.J (1996) An improved onepot procedure for the symthesis of alkyues frotn aldelydes. SynLet1 06:521-522

Ohica $S$ (1989) Melhanolysis of dinethy] (1-dias-2-oxopropyl) phosphonale: generation of dimethyl (divzomethyl) phosphonate and reaction with carbonyt compounds. Syoth Comrn $19(3-4) 561-564$

Passintent M, Koskinen AM (2013) Garner's aldelyde as a versatile intenmediate in Ife synthesis of enantiopure natural proctucls. Beilstein J Ore Chom $9(1) 2641-2659$

Pletrozka J, Wit A. Frey W (2003) Sythesis of "Garner" Aldehycte-Derived Cyclopropylboronic Esters. Eur I Ore Chem $16 \div 3219-3229$

Puiley SR, Sen $S$, Voroguslin A, Swanson E (1999) Diaryl ellers using jischer chronium carbene medialed beratonmation. Org Lett $\mathrm{E}(11): 1721-1723$

Pultoy 5R, C7ak6 B, Brown GD (2005) Synthesis of arylglycines via the Dolz benzannutation reaction. Tetrahedron Lell $46(52): 9039-9042$

Rajj Reddy C, Krishna G. Kavitha N. Latha B, Shin ĐS (2012) Acces to 2, 3-disubstituled benzortrans through one-pot acid-catalyzed nucteop titic substitulion/TBAF-mediared oxacycloisoncrization. Euг $f$ Org Chem 2012(27):5381-5388 
Reginato G, Mordini A. Degl'Innocenti A, Caraccioto M (1995) Sterenselective synthesis of (R)-(-)-2, 2-dimellyl-3-i-butoxycarbonyl-4-ethynyl-oxicolidine: a chiral building block for the synthesis of a ncw class of substituled alkynes. Telrahedron Let $36(45): 8275-8278$

Reginato G. Mordini A. Caracciolo M (1997) Synthetic elaboration of the side chati of (R)-2, 2-dinethyl-3-(telt-butoxycarbonyl)4-ethynyloxazolidine; a new regio-alud stercoselective strategy 10 s-lunctionalized P-amino alcohols. J Ory Chem $62(18): 6187-6: 92$

Reginato G. Mordin A. Cappenueci A, Degl'Innocenti A, Manganictlo $S$ (1998) Stereoselective synthesis of new enantionerically eniched N-protected $\gamma$-antino acetylenic esters. Telathedron 54(34): $10217-10226$

Reginato $G_{r}$ Meffre P. Gaggini $F$ (2005) Elhynylglycine synthon fron Gamer's aldelyde: a useful procursor for the symthesis of nonratural anino acids. A mino Acids 29(2):81-87

Reginito $G$. Mordini. $A$, Meffre $P$, Tenti A, Vataccli M. Cariou $K$ (2006) Now unsalurated amino acids containing an ally]silane moiety on the lateral chain. Tetmacciron Asymmetry $17(6): 922-926$

Serat $X$, Cabarrocas $G$. Rafel $S$, Ventura M, Linden A, Vijalgordo IM [1999) A bighly efficiemt and straightforward stereoseleclive synthesis of movel chiral d-acetyenic ketones. Tetrahedron Asymmetry 10(17):3417-3430
Spangenlyerg T, Selhoenfelder A, Breil B, Mamn A (2010) 1,2-diastereosclective c-e bond-forning reactions for the synthesis of chiral B-branched $\alpha$-amino acids. Eur \& Org Chem $31: 6005-6018$

Stecko 5, Manes A. Furman B, Chtnielew ski M (2009) Asymmetric kinugasa reaction of cyclic nitrones and nonvacenic acelylenes. J Org Chem $74(8): 3094-3100$

Femperini A, Capperucei A, Degl'unnocenti A, Terlizzí R, Tiecco M (20t0) A reasonably slereospecific multistep conversion of Bocprotected $\alpha$-amino acids to Plth-protected $\beta^{3}$-amino acids. "letrahedron Lell $51(31): 4121-4124$

Usuki T, Yamada H, Hayashi T, Yanuma H, Koscki Y, Sutzukj N, Lin YY (2012) Total synthesis of COPD biomatker desmosine that crosslinks vfustin. Chen Conntun 48(26):3233-3235

Yamakawa $T$, Ideae $E$, Shimokawa J, Fukbyama $T$ (20/0) Total symuliesis of tryprosiatins $A$ and $B$. Angew Chem Int $E d$ $49(48): 9262-9265$

Yamakawa T. Tdene E, Iwaki Y, Sato A. Tokaytuma H. Shimokitwa f, Fukuyarna $T$ (2011) Total synthesis of typrostatins A and B. Telrahedron $67(35): 6547.6560$

Yanada $R$, Obika 5. Kobayashi $Y$, lnokuma T, Oyama M, Yanada K, Takentoto $\mathrm{Y}$ (2005) Stercoselective synthesis of 3-alkylidencoxindoles using tandem indiun-mediated carbometallation and palladium-catayzed cross-coupling reactions. Adv Syuls Catal $347(11-17): 1632-1642$ 